\title{
Efektifitas Penurunan Mn dan Total Coliform Pada Air Sumur Gali Berbasis Zeolit
}

\author{
Nur Rachmah**) dan Setyo Purwoto*)
}

\begin{abstract}
Abstrak
Salah satu tujuan pemerintah dalam mencapai starategi Millenium Development Goals (MDGs) adalah terpenuhinya kebutuhan penduduk akan air bersih yang memenuhi syarat kesehatan. Air bersih yang memenuhi syarat yang dimaksudkan adalah air yang memenuhi baku mutu Permenkes No. 416/MENKES/PER/IX/1990, disamping itu masyarakat mampu mengakses air bersih sebesar 73\% hingga tahun 2015. Akan tetapi kondisi air sumur di Kelurahan Wates Kota Mojokerto rata -rata kandungan Mn dan Total Coliform tidak memenuhi syarat, oleh karena itu perlu dilakukan penelitian dengan menggunakan teknologi filtrasi untuk memecahkan masalah tersebut. Penelitian ini telah dilaksanakan dengan menggunakan media zeolit alam, manganese green sand dan zeolit yang teraktivasi dengan pemanasan, dengan tujuan untuk mengetahui efektifitas media filtrasi zeolit alam, manganese green sand dan zeolit teraktivasi dengan pemanasan dalam menurunkan Mn dan Total Coliform. Penelitian ini dilakukan dengan metode eksperimen dengan variabel bebas : Filter zeolit alam, Manganese Green Sand dan Zeolit teraktivasi dengan pemanasan, serta variabel terikat kandungan Mn dan Total Coliform.Reaktor yang digunakan sebanyak tiga buah dengan tinggi $100 \mathrm{~cm}$, ketinggian media $60 \mathrm{~cm}$, diameter zeolit alam mess 16 - mess 7, diameter manganese green sand mess 30 - mess 12 dan diameter zeolit teraktivasi dengan pemanasan mess 16 - mess 7 . Pada saat proses penelitian air baku di treatment dengan debit 1 liter / menit selama 60 menit dengan interval waktu 15 menit untuk diambil sampelnya. Metode analisa laboratorium untuk pemeriksaan kandungan $\mathrm{Mn}$ menggunakan metode AAS (Atomic Absorbs Spectrofotometer) dan Total Coliform menggunakan metode tabung ganda.Dari hasil penelitian ini di dapatkan: media filter zeolit alam efektif menurunkan kandungan $\mathrm{Mn}$ dari 2,53 mg/lt menjadi < 0,01 $\mathrm{mg} / \mathrm{lt}$ akan tetapi tidak efektif dalam menurunkan kandungan Total Coliform. Untuk media filter manganese green sand efektif menurunkan kandungan $\mathrm{Mn}$ dari 2,53 mg/lt menjadi < 0,01 mg/lt dan efektif menurunkan Total Coliform pada menit ke - 60. Sedangkan media filter zeolit teraktivasi panas efektif menurunkan kandungan $\mathrm{Mn}$ rata -rata sebesar 0,099 $\mathrm{mg} / \mathrm{lt}$ dari 2,53 $\mathrm{mg} / \mathrm{lt}$ akan tetapi kurang efektif dalam menurunkan kandungan Total Coliform. Dari tiga media yang digunakan untuk penelitian ini, media filter manganese green sand paling efektif dalam menurunkan kandungan Mn dan Total Coliform
\end{abstract}

Kata Kunci : Filtrasi, Manganese Green Sand, Mn, Total Coliform, Zeolit.

PENDAHULUAN

Millenium Development Goals

(MDGs) atau Tujuan Pembangunan Milenium mempunyai ringkasan arah pembangunan global salah satunya adalah menjamin keberlangsungan lingkungan dengan strategi menurunkan hingga setengahnya proporsi rumah tangga tanpa akses berkelanjutan terhadap air bersih yang layak dan sanitasi dasar.Dengan harapan target masyarakat sudah terpenuhi akses air bersih yang memenuhi syarat sebesar $73 \%$ hingga tahun 2015 (MDGs Provinsi Jawa Timur, 2011). Akan tetapi mengacu pada data hasil pemeriksaan sampel mikrobiologi 137 air sumur gali dan sumur bor diperoleh 78 air positif Coliform dan 59 negatif Coliform. Dan dari hasil pemeriksaan laboratorium kandungan Mn pada air sumur gali salah satu penduduk Wates Mojokerto diperoleh 2,33 mg / Itdan kandungan Total Coliform sebesar > 2400 MPN / 100 It. Ratarata kandungan Air Bersih Parameter Mn dan Total Coliform di Kelurahan Wates Kota Mojokerto tidak memenuhi baku mutu air bersih, sehingga berdampak tingginya angka diare di wilayah tersebut.Oleh karena itu dilakukan penelitian dengan teknologi filtrasi, untuk memecahkan permasalahan tersebut. Dari penelitian yang dilakukan oleh Hadini (2011) dengan menggunakan filter mangan zeolit terhadap sumur gali, didapatkan efesiensi removal konsentrasi $\mathrm{Mn}$ sebesar $97,14 \%$ dari kadar awal 2,5 mg/l menjadi $0,071 \mathrm{mg} / \mathrm{l}$ dengan ketebalan media $40 \mathrm{~cm}$ dan diameter $2 \mathrm{~mm}$.

**) Mahasiswa Teknik Lingkungan

*) Dosen Teknik Lingkungan Universitas PGRI Adi Buana Surabaya 
Selain itu Iknasius (2011) telah melakukan penelitian dengan menggunakan media pasir biji besi dapat menurunkan coliform sebesar $219 / 100 \mathrm{ml}$ sampel atau $91,25 \%$ dalam waktu 6 menit. Oleh sebab itu penelitian ini menggunakan media Zeolit Alam, Manganese Green Sand dan Zeolit Teraktivasi dengan Pemanasan. Tujuan penelitian ini untuk mengetahui efektifitas media filtrasi zeolit alam, manganese green sand dan zeolit teraktivasi dengan pemanasan dalam menurunkan $\mathrm{Mn}$ dan Total Coliform . Manfaat yang ingin dicapai dalam penelitian ini adalah hasil penelitian ini dapat diterapkan kepada masyarakat dalam memecahkan masalah air dengan kandungan $\mathrm{Mn}$ dan Total Coliform yang tinggi pada air sumur dan hasil penelitian ini dapat ditindaklanjuti oleh Dinas Kesehatan atau Dinas terkait dalam mewujudkan citacita MDGs

\section{METODE PENELITIAN}

1. Rancangan Penelitian

Penelitian yang dilakukan adalah penelitian eksperimen dengan rancangan seperti pada gambar 1

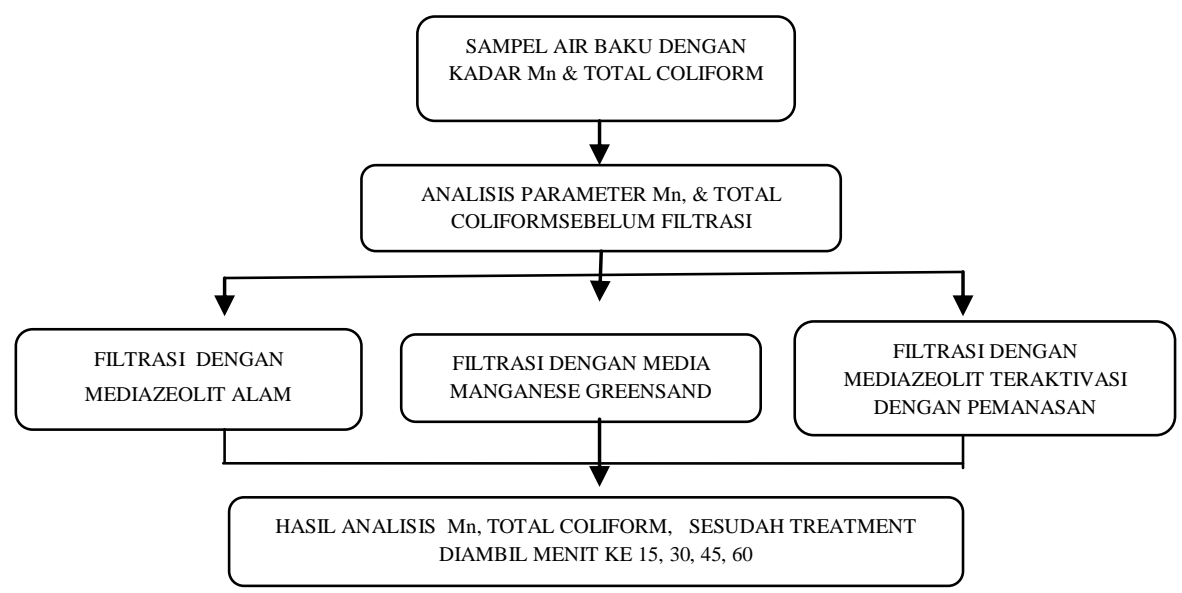

Gambar 1 :Rancangan Penelitian

Dalam penelitian ini yang menjadi variabel bebas adalahfilter zeolit alam, manganese green sand dan zeolit teraktivasi dengan pemanasan dan variabel terikat : kandungan $\mathrm{Mn}$ dan Total Coliform.

2. Populasi dan Sampel

Populasi dalam penelitian ini adalah air sumur gali warga Kelurahan Wates Kecamatan Magersari Kota Mojokerto, dan sampel yang digunakan dalam penelitian ini adalah air sumur gali milik ibu Sani yang bertempat tinggal di Bancang gang Cempaka No. 16 kelurahan Wates Kecamatan Magersari Kota Mojokerto

3. Persiapan alat dan bahan penelitian

a. Persiapan mediazeolit alam dan zeolit teraktivasi dengan pemanasan

1) Diameter yang digunakanmess 16 - mess 7.

2) Untuk media zeolit alam tidak diberikan perlakuan apapun sedangkan zeolit teraktivasi dengan pemanasan diberi perlakuan pemanasan dengan menggoreng di atas kompor selama 1 (satu) jam.

b. Persiapan media Manganese Greensand

Media Manganese Greensand yang digunakan dengan diameter mess 30- mess 12

c. Persiapan media filter cloth

Filter cloth dalam bentuk lembaran persegi empat, dipotong - potong dengan dimensi keliling lingkaran berdiameter $15,8 \mathrm{~cm}$

d. Penyusunan media ke dalam reaktor Sebelum media dimasukkan ke dalam reaktor, kebutuhan jumlah media yang diinginkan dengan ketebalan $60 \mathrm{~cm}$, yangterdiri atas $59,3 \mathrm{~cm}$ untuk ketebalan inti media dan $0,7 \mathrm{~cm}$ media filter cloth dikonversi terlebih dahulu ke dalam satuan liter dengan menggunakan rumusvolume tabung $=\left(\frac{\pi}{4} D^{2}\right) \times h$

e. Pembuatan Reaktor / Filtrasi

Dalam penelitian ini dilaksanakan menggunakan pipa PVC 6 inch dengan ukuran tinggi $100 \mathrm{~cm}$ 
sebanyak 3 buah.Kedua ujung pipa diberi tutup dop. Untuk inlet dan out let reaktor filter diberi lubang dengan mengebor sebesar $3 / 4$ inch ukuran pipa dengan jarak $20 \mathrm{~cm}$ dari ujung pipa.Pembatas antara ruang kosong dengan media filter terbuat dari akrilik yang dilubangi dengan soder sehingga membentuk seperti sarangan. Semua bahan yang akan dirangkai dicuci supaya bebas dari kotoran dan dibilas dengan air panas.Salah satu contoh pembuatan reaktor seperti pada gambar 2

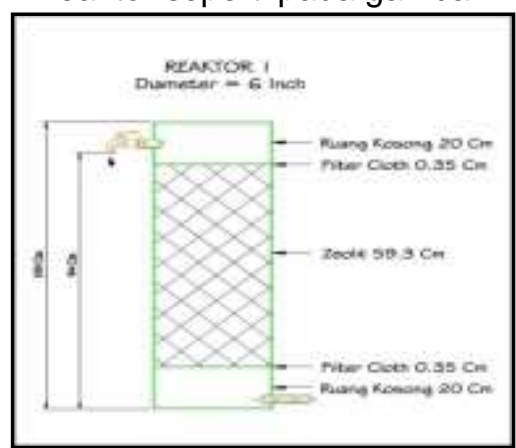

Gambar 2 : Gambar Potongan Filtrasi

f. Tandon Tandon yang digunakan sebanyak 1 buah dengan volume 120 liter

g. Penyangga tandon Penyangga tandon untuk tempat tandon dengan ketinggian $200 \mathrm{~cm}$

h. Pengatur Debit

Bak ini berfungsi untuk mengatur stabilisasi debit yang akan masuk ke reaktor. Volume bak pengatur debit ini sebesar 2 liter

i. Bak penampung limpahan

Dibawah bak pengatur debit ini disediakan bak penampung limpahan air.

j. Instalasi unit percobaan

Desain reaktor dan gambar irisan memanjang reaktor, sepertigambar3

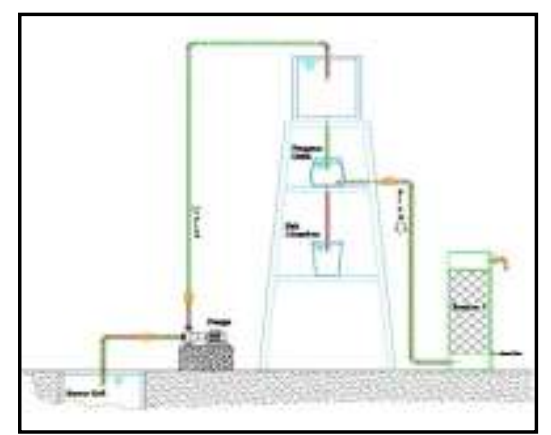

Gambar 3 : Gambar Rangkaian Percobaan Filtrasi
4. Teknik Pengumpulan Data :

a. Merangkai percobaan filtrasi seperti gambar 3

b. Menghitung debit yang keluar dari reaktor, dilakukan berulang-ulang hingga diperoleh debit yang stabil

c. Menentukan beda tinggi muka air $(\Delta \mathrm{H})$

Menentukan beda tinggi muka air $(\Delta \mathrm{H})$ yang dapat diperoleh dengan rumus :

$\Delta \mathrm{H}=\mathrm{H}_{2}-\mathrm{H}_{1}$

$\mathrm{H}_{2}=$ Tinggi muka air bak pengatur debit

$\mathrm{H}_{1}=$ Tinggi pipa outlet reaktor filter

Untuk mendapatkan debit 1 liter / menit diperoleh tinggi muka air bak pengatur debit sebesar :

1). Reaktor filter I $\left(H_{2}\right)=108 \mathrm{~cm}$

Jadi $\Delta \mathrm{H}_{1}=\mathrm{H}_{2}-\mathrm{H}_{1}$

$=108-94=14 \mathrm{~cm}$

2). Reaktor filter II $\left(\mathrm{H}_{2}\right)=108 \mathrm{~cm}$

Jadi $\Delta \mathrm{H}_{2}=\mathrm{H}_{2}-\mathrm{H}_{1}$

$=108-93=15 \mathrm{~cm}$

3). Reaktor filter III $\left(\mathrm{H}_{2}\right)=106 \mathrm{~cm}$

Jadi $\Delta \mathrm{H}_{3}=\mathrm{H}_{2}-\mathrm{H}_{1}$

$=108-9=14 \mathrm{~cm}$

d. Pengukuran suhu air sampel $\left(\mathrm{T}^{\circ} \mathrm{C}\right)$

Suhusampel air padareaktor $\mathrm{I}=29$

${ }^{\circ} \mathrm{C}$, reaktor $\mathrm{II}=27^{\circ} \mathrm{C}$ dan reactor $\mathrm{III}=$ $30^{\circ} \mathrm{C}$.

e. Koefisien Permeabilitas (k)

Koefisien permeabilitas dapat

diperoleh melalui hukum Darcy

$\mathrm{Q}=\underline{\mathrm{A} \cdot \mathrm{k} \Delta \mathrm{H} \cdot \mathrm{t}}$

f. Running percobaan dengan langkahlangkah sebagai berikut :

1) Penguji cobaan stabilitas debit dengan menggunakan aquadest

2) Setelah diperoleh debit outlet reaktor filter stabil 1 liter/menit

3) Air sampel sumur dipompa ke tandonkemudian kran dari tandon dibuka hingga air memenuhi bak pengatur debit

4) Sampel sumurdari bak pengatur debit langsung masuk ke Reaktor filter

5) Mengambil sampel air sumur sebelum masuk reaktor filter pada outlet pengatur debit

6) Mengambil sampel yang sudah melalui reaktor filter pada menit ke $15,30,45,60$

7) Memberi label pada botol sampel dan dikirim ke Labratorium 


Analisis Pemeriksaan Mn
dengan metode AAS (APHA
standards method 3111 B) dan
cara menguji kandungan Total
Coliformdengan metode tabung
ganda

5. Teknik Analisis Data

Analisis data dalam penelitian ini menggunakan perhitungan efektifitas penurunan dengan membandingkan kadar parameter pre treatment dan post treatment. Selanjutnya disajikan dalam bentuk tabel untuk membandingkan efektifitas reaktor dengan variasi media yang berbeda. dan variasi waktu.Data penelitian dibandingkan dengan baku mutu air bersih yang mengacu pada Permenkes no.416/Menkes/Per/IX/1990.

\section{HASIL PENELITIAN}

1. Perhitungan efektifitas penurunan $M n$ Perhitungan efektifitas reaktor filter dalam menurunkan $\mathrm{Mn}$ tersaji dalam Tabel 1 :

Tabel 1 : Efektifitas Penurunan Mn Antara Media Filter Manganese Green Sand dan Zeolit Teraktivasi dengan Pemanasan

\begin{tabular}{cccc}
\hline Menit ke - & Zeolit Biasa (\%) & Manganese Green Sand (\%) & Zeolit teraktivasi dengan pemanasan (\%) \\
\hline 15 & Tidak terdeteksi & Tidak terdeteksi & 99 \\
30 & Tidak terdeteksi & Tidak terdeteksi & 96 \\
45 & Tidak terdeteksi & Tidak terdeteksi & 95 \\
60 & Tidak terdeteksi & Tidak terdeteksi & 92 \\
\hline
\end{tabular}

Untuk memperjelas perbandingan penuruna $\mathrm{Mn}$ Media Zeolit teraktivasi dengan pemanasan dalam interval 15 menit selama 60 menit, maka akan digambarkan pada gambar 4 berikut ini :

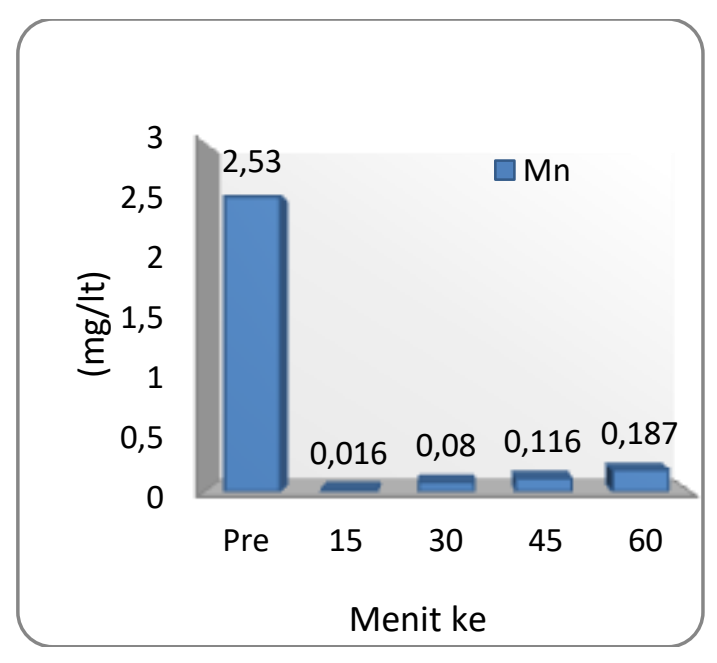

Gambar4. Grafik Efektifitas Penurunan Mn PadaMedia Filter Zeolit Teraktivasi dengan Pemanasan

2. Perhitungan efektifitas penurunan Total Coliform

Perhitungan efektifitas penurunan Total Coliform tidak bisa dilakukan perhitungan dalam bentuk persentase karena hasil yang diperoleh setelah dilakukan filtrasi sebesar angka tidak terhingga atau sama dengan 2400 MPN/100 ml.

\section{PEMBAHASAN}

1. Analisis Mn

Tabel 1. Kadar Mn hasil filtrasi antara Zeolit, Manganese Green Sand dan Zeolit teraktivasi dengan pemanasan dengan variasi waktu, menit ke 15,30 , 45 dan 60, menunjukkan hasil yang memenuhi baku mutu air bersih / Permenkes RI No. 416/Menkes/Per/IX/1990 yang menyatakan bahwa kadar $\mathrm{Mn}$ untuk air bersih maksimal yang diperbolehkan adalah $0,5 \mathrm{mg} / \mathrm{lt}$.

Hubungan antara efektifitas penurunan $\mathrm{Mn}$ dengan variasi waktu

a. Media filter Zeolit alam dan Manganese Green Sand :

Untuk media Zeolit alam dan Manganese Green Sand efektifitas penurunan $\mathrm{Mn}$ dari $2,53 \mathrm{mg} / \mathrm{l}$ menjadi< 0,01 mg/l tidak terdeteksi oleh karena penurunan yang sangat tinggi yaitu diperoleh hasil dibawah limit deteksi pembacaan dari spectrofotometer.

Demikian juga pada media Manganese Green Sand, selain berdiameter paling kecil, $\mathrm{K}_{2} \mathrm{Z} . \mathrm{MnO}$. $\mathrm{Mn}_{2} \mathrm{O}_{7}$ dapat berfungsi sebagai katalis dan sehingga $\mathrm{Mn}$ yang ada dalam air,teroksidasi menjadi bentuk mangan dioksida yang larut dalam air.

Reaksinya sebagai berikut :

$\mathrm{K}_{2} \mathrm{Z} . \mathrm{MnO} \cdot \mathrm{Mn}_{2} \mathrm{O}_{7}+2 \mathrm{Mn}\left(\mathrm{HCO}_{3}\right)_{2} \rightarrow$ $\mathrm{K}_{2} \mathrm{Z}+5 \mathrm{MnO}_{2}+4 \mathrm{CO}_{2}+2 \mathrm{H}$ 
Kemudian fitrat yang terbentuk dapat dipisah kandengan pengendapan dan penyaringan.

b. Media filter Zeolit teraktivasi dengan pemanasan:

Padamenitke-15 efektifitas penurunan $99 \%$ (dari $2,53-0,016$ $\mathrm{mg} / \mathrm{l})$, padamenitke-30 efektifitas penurunannya $97 \%$ (dari 2,53 $0,080 \mathrm{mg} / \mathrm{l})$, padamenitke-45 efektifitas penurunannya $95 \%$ (dari $2,53-0,116 \mathrm{mg} / \mathrm{l})$, pada menit ke60 efektifitas penurunannya $92 \%$ (dari 2,53-0,187 mg/l), rata-rata efektifitas penurunannya $96 \%$. Pada gambar4 grafik efektifitas penurunan menunjukan semakin lama proses filtrasi semakin menurun persentase efektifitasnya, hal ini bisa terjadi karena aktivasi asam dan pemanasan dapat menyebabkan terjadinya perubahan struktur pada zeolit alam, yaitu penurunan kadar sebagian besar kation yang berpengaruhterhadap aktivasi katalitik (Tina Rosdiana, 2006)

2. Analisis Total Coliform

Dari pemeriksaan Total Coliform dari ketiga jenis media filter, semuanya tidak sesuai dengan baku mutu air bersih / Permenkes RI No. 416/Menkes/Per/IX/1990 yang menyatakan bahwa kandungan Total Coliform setiap $100 \mathrm{ml}$ air bersih dengan sumber sumur terbuka, batas maksimal diperbolehkan adalah 50 MPN

Hubungan antara efektifitas penurunan Total Coliform dengan variasi waktu, pada :

a. Media zeolit alam

Post treatment pada media zeolit alam diperoleh hasil > 2400 MPN/100 ml sehingga tidak terjadi penurunan kandungan Total Coliform dari $>2400 \mathrm{MPN} / 100 \mathrm{ml}$ tetap menjadi > $2400 \mathrm{MPN} / 100 \mathrm{ml}$, sehingga dapat disimpulkan bahwa media zeolit alam tidak efektif dalam menurunkan kandungan Total Coliform.

b. Media manganese green sand Post treatment pada media manganese green sand, pada menit ke-15 dari> 2400 MPN /100 It turun menjadi $1600 \mathrm{MPN} / 100 \mathrm{lt}$, pada menit ke -30 dan ke-45 diperoleh hasil dari> 2400
MPN/100 It tetap menjadi> 2400 MPN/100 ml dan pada menit ke 60 diperoleh hasil dari> 2400 MPN/100 ml turun menjadi 81 MPN/100 It. Dari data tersebut dapat disimpulkan bahwa media manganese green sand efektif menurunkan kandungan Total Coliform pada menit ke-60 .Saringan pasir lambat melalui proses adsorbsi dan proses lain,bakteri dapat dihilangkan dari air dan ditahan pada permukaan butiran pasir yaitu kira-kira $85-99 \%$ total bakteri, dan dapat menghasilkan air yang memenuhi syarat bakteriologi yaitu air yang tidak mengandung eschericia coli.

c. Media zeolit teraktivasi dengan pemanasan

Post treatment pada media zeolit teraktivasi dengan pemanasan. Telah diperoleh penurunan terbesar pada menit ke -45 yaitu 81 MPN/100 ml dari>2400 MPN/100 $\mathrm{ml}$, sedangkan pada menit sebelum dan sesudahnya mengalami penurunan yang tidak stabil, hal ini bisa terjadi karena peneliti pada saat memberikan pemanasan pada media zeolit (reaktor III) tidak memperhatikan suhu pemanasan, jadi kemungkinan perlakuan pemanasan dengan cara menggoreng media telah melebihi ketahanan zeolit pada suhu maksimal, sehingga menurut Kirk Othmer (1998) dalam karya Dian Kusuma dan Anthonius (2010) apabila zeolit dipanaskan melebihi temperature maksimalnya maka akan merusak struktur zeolit itu sendiri. Dengan rusaknya struktur di dalam Kristal akan mengakibatkan berkurangnya ruang-ruang hampau dara di dalam zeolit dan akhirnya akan mengurangi daya adsorpsi zeolit.

\section{KESIMPULAN DAN SARAN Kesimpulan}

Dari hasil penelitian tersebut diatas dapat disimpulkan sebagai berikut : Media filter zeolit alam sangat efektif dalam menurunkan kandungan $\mathrm{Mn}$ dari $2,53 \mathrm{mg} / \mathrm{tt}$ menjadi < $0,01 \mathrm{mg} / \mathrm{lt}$ akan tetapi tidak efektif dalam menurunkan kandungan Total Coliform. Media filter manganese green sand sangat 
efektif dalam menurunkan kandungan $\mathrm{Mn}$ dari $2,53 \mathrm{mg} / \mathrm{tt}$ menjadi $<0,01 \mathrm{mg} / \mathrm{lt}$ dan efektif pula dalam menurunkan Total Coliform pada menit ke - 60 . Media filter zeolit teraktivasi dengan pemanasan efektifitas menurunkan kandungan $\mathrm{Mn}$ sebesar $96 \%$ akan tetapi kurang efektif dalam menurunkan kandungan Total Coliform. Dari tiga media yang digunakan untuk penelitian ini, media filter manganese green sand paling efektif dalam menurunkan kandungan Mn dan Total Coliform

\section{Saran}

Demi kesempurnaan penelitian ini penulis memberikan saran-saran sebagai berikut :
Perlu dilakukan penelitian lebih lanjut mengenai suhu dan lama pemanasan, untuk mengetahui kondisi perlakuan yang tepat dalam mengaktivasi zeolit secara fisik sehingga mendapatkan hasil efektifitas penurunan kadar $\mathrm{Mn}$ dan Total Coliform yang signifikan. Perlu dilakukan penelitian lebihlanjut dengan variasi waktu kontak lebih dari 60 menit, untuk mengetahui pengaruh waktu kontak terhadap penurunan kadar Mn dan Total Coliform.Penelitian yang berhubungan dengan sterilitas atau mikroorganisme sebaiknya dilakukan di ruang tertutup dan steril agar penelitian menghasilkan data yang lebih teliti.

\section{DAFTAR PUSTAKA}

Abdurrahman, Budi, Departemen kesehatan Lingkungan, Fakultas Kesehatan Masyarakat, UI, 2004, Makara kesehatan Penyaringan air tanah dengan zeolit alami untuk menurunkan kadar besi dan mangan, Jakarta Departemen Kesehatan RI, Dirjen Penyehatan Air, Ditjen PPM \&PLP, 1998, Pedoman Upaya Penyehatan Air Bagi Petugas Sanitarian Puskesmas, , Jakarta

Anonymus, Pembuatan Filter Untuk Menghilangkan Zat Besi dan Mangan Di Dalam Air, http:www.enviro.bppt.go.id / Kel-1/(Tanggal Mengunduh : 19 April 2012)

Anonymus, Bahan-bahan Media Filtrasi, Smk Negeri 3 Kimia Madiun, http : //.htm (Tanggal Mengunduh : 19 April 2012)

Anonymus, Anisa, Ariani, 2005 Evaluasi Kondisi Sumur Gali Dalam Kaitannya Dengan Pencemaran Logam Berat (Studi Kasus : Desa Bojongsari Kecamatan Bojongsoang Kabupaten Bandung). Tesis Fakultas Teknik Sipil dan Perencanaan Institut Teknologi Bandung, Bandung,

http://digilibampl.net/detail/list.php?row=3\&ktg=tesis\&tp=pustaka\&kdlink(Tanggalmengunduh : 19 April 2012)

Anonymus, Kumpulan teknik penyaringan air sederhana,http://aimyaya.com/id/lingkunganhidup/kumpulan-teknik-penyaringan-air-sederhana/ (Tanggal mengunduh : 20 Juli 2012)

Anonymus, Zeolit potensi alam indonesia yang fenomenal, http://vedcadiklatki.blogspot.com/2012/04/zeolit-potensi-alam-indonesia-yang.html (Tanggal mengunduh : 20 Juli 2012)

Anonymus, Logam dan Manfaatnya Bagi tubuh Manusia,http: // pusatgamat.com/artikelartikel/logam-dan-manfaatnya-bagi-tubuh-manusia, (Tanggal mengunduh : 20 Juli 2012)

Anonymus, Metode Praktis Penghilangan Zat Besi dan Mangan di Dalam Air Minum, www.kelair.bppt.go.id/Publikasi/Buku Air Minum/BAB7Filter.Pdf (Tanggal mengunduh : 30 Desember 2012)

Christady Hary, 2010, Mekanika Tanah 1, Gadjah Mada University Pres, Yogyakarta

Departemen Kesehatan RI, 1990, Peraturan Menteri Kesehatan Nomor 416/MEN.KES/PER/IX/1990 Tentang Syarat-syarat dan Pengawasan Kualitas Air, Jakarta

Dian Kusuma, Anthonius, 2010, Optimasi Aktivasi Zeolit Alam untuk Dehumidifikasi, Universitas Diponegoro, Semarang

Karnaningroem, Hardini, 2011, Peningkatan Kualitas Air Sumur Gali Menjadi Air Bersih Menggunakan Filter Mangan Zeolit dan Karbon Aktif : Studi Kasus Air Sumur Gali Pemukiman desa Banjar PO Sidoarjo, Skripsi Mahasiswa Jurusan Teknik lingkungan ITS, Surabaya

Kusnaedi, 2010, Mengolah Air Kotor Untuk Air Minum,Penebar Swadaya, Jakarta

Pemerintah Propinsi Jawa Timur, 2011, Rencana Aksi Daerah Percepatan Pencapaian Tujuan Pembangunan Millenium di Popinsi Jawa Timur Tahun 2011-2015, Surabaya

Rosdiana Tina, 2006, Pencirian dan Uji Katalitik Zeolit Alam Teraktivasi, Fakultas Matematika dan IImu Pengetahuan Alam IPB ,Bogor

Sarudji, Didik, 2010, Kesehatan Lingkungan, Karya Putra Darwati, Bandung 
Nur Rachmah \& Setyo Purwoto : Efektifitas Penurunan Mn dan Total Coliform Pada Air Sumur Gali Berbasis Zeolit

Standard Methods, 2005, Standard Methods for The Examination of Water and Waste Water, American Public Health Association, Washington DC

Yudhastuti, Tesis Fakultas Kesehatan Masyarakat, UI, 1993, Studi Kemampuan Zeolit untuk Menurunkan Jumlah Kuman Coliform Air sungai Ciliwung, Jakarta 